\title{
The Limits of Koreanness
}

DOI:

10.2307/j.ctv1g13jn6.22

\section{Document Version}

Accepted author manuscript

Link to publication record in Manchester Research Explorer

\section{Citation for published version (APA):}

Pulford, E. (2021). The Limits of Koreanness: Korean Encounters in Russo-Chinese Yanbian. In A. Cathcart, C. Green, S. Denney, \& W. van Schendel (Eds.), Decoding the Sino-North Korean Borderlands (pp. 401-430). (Decoding the Sino-North Korean Borderlands). Amsterdam University Press.

https://doi.org/10.2307/j.ctv1g13jn6.22

\section{Published in:}

Decoding the Sino-North Korean Borderlands

\section{Citing this paper}

Please note that where the full-text provided on Manchester Research Explorer is the Author Accepted Manuscript or Proof version this may differ from the final Published version. If citing, it is advised that you check and use the publisher's definitive version.

\section{General rights}

Copyright and moral rights for the publications made accessible in the Research Explorer are retained by the authors and/or other copyright owners and it is a condition of accessing publications that users recognise and abide by the legal requirements associated with these rights.

\section{Takedown policy}

If you believe that this document breaches copyright please refer to the University of Manchester's Takedown Procedures [http://man.ac.uk/04Y6Bo] or contact uml.scholarlycommunications@manchester.ac.uk providing relevant details, so we can investigate your claim.

\section{OPEN ACCESS}




\title{
18 The Limits of Koreanness ${ }^{1}$
}

\section{Korean Encounters in Russo-Chinese Yanbian}

\author{
Ed Pulford
}

\begin{abstract}
Chinese Joseonjok (ethnically Korean citizens of the PRC) and Russian-speaking Goryeo saram (Koreans from the former-USSR) have each witnessed unprecedented domestic shifts affecting their relationships and senses of belonging within their own countries, along with myriad new opportunities for international mobility. This in turn has led to contact with manifestations of 'Koreanness' very different from those which had emerged over the $20^{\text {th }}$ century in the Chinese and Soviet contexts. This chapter deals ethnographically with the experiences of Russian Goryeo saram in Yanbian, a Joseonjok autonomous prefecture in northeast China, to examine the negotiations over 'Koreanness' and other forms of national and ethnic belonging which emerge in encounters between two peoples broadly classified as 'Korean', but neither from a 'Korean' country.
\end{abstract}

Keywords: Chinese Koreans, Chinese minority policy, Chosonjok, Korean identity, Soviet Koreans, Yanbian

\section{Introduction}

On a sweltering August afternoon on Century Square, an expansive plaza in the small northeastern Chinese town of Hunchun, I sit on a bench with Avram, a Goryeo saram ${ }^{2}$ in his mid-70s. A short distance across the square, a collective of middle-aged Han Chinese and Joseonjok women is practising a synchronized dance routine as the sun beats down, swaying and twisting to jaunty but distorted music emanating from a speaker perched on the paving. ${ }^{3}$ In another corner, a score or so of elderly locals is watching an impromptu performance of errenzhuan, a northeastern Chinese form of spoken and sung theatre accompanied by squeaky suona horn and plucked erhu, the twostringed Chinese fiddle. Avram is enjoying these displays of uninhibited spontaneity among elderly locals, and gestures towards some of the dancers.

\footnotetext{
${ }^{1}$ This paper is based on fieldwork conducted in Yanbian Korean Autonomous Prefecture in 2014-2015 and 2017. I am grateful to the generous support of the pre-doctorial fellowship programme at the Academy of Korean Studies (AKS) in Seongnam, ROK, which made available resources and a stimulating scholarly community greatly aiding the development of the ideas presented here.

${ }^{2}$ Literally meaning 'Goryeo person', Goryeo saram (Корё сарам) is the self-designation of ethnically Korean citizens of the former-Soviet Commonwealth of Independent States (CIS). In South Korea (Republic of Korea, ROK), this group is more often known as Goryeo in (고려 인), also denoting 'Goryeo people'.

${ }^{3}$ Joseonjok is the official label given to the Korean minority (population c. 2 million) in the People's Republic of China (PRC).
} 
'It's great that they're not shy about doing that, and no one's laughing at them', he says. 'When I was out here on the square a few weeks ago a man approached me from one of the dance groups and started encouraging me to join in, showing me all the moves. If anything like that happened in Russia everyone would just think "what the hell is wrong with you, have you lost your mind? Get this guy to a mental hospital!" But here there's none of that cynicism'.

Avram's background makes him well qualified to perceive such differences between appropriate public and private behaviour, the reasons for which one might accuse others of being deranged, and many more Sino-Russian inter-cultural Othernesses. Born in Kazakhstan but raised in Uzbekistan by parents who were forcibly deported from the Soviet Far East to Central Asia in 1937 along with around 200,000 Goryeo saram (Martin 2001; Chang 2016), Avram has spent years of his life in each of Central Asia, Russia and, since 2011, China. As we talk, conversation about the broad contours of cultural difference between these countries and regions, as well as North and South Korea, features prominently, prompted only in part by my own line of questioning. He enjoys discussing the myriad ethnic and cultural differences in the multi-layered and shifting sphere of Soviet cosmopolitanism where he spent the first decades of his life. As well as the most obvious distinctions between groups who had their own Soviet republics - Kazakhs, Uzbeks, Russians, Soviet Uyghurs, Karakalpaks, Muslim Chinese Dungans, Koreans and many others - important lines of differentiation also existed, Avram reports, among Soviet Koreans.

'We Central Asian Goryeo saram are all otorvannye (“cut off”) Koreans', he says, in laconic reference to the deportation. 'But Koreans from Kazakhstan are very different to those from Uzbekistan. Kazakhstan is a huge country with few people, and they are a lot more Russianized, so the Kazakh Koreans there are more "civilized". In Uzbekistan where I grew up, the population is much bigger and Koreans live in small villages among locals who are considered ostalye ("backward") and only speak Uzbek, so we had to work a lot harder to learn good Russian and make progress'. Atypically for those born in Central Asia, Avram was raised speaking both Russian and Korean; many of his generation retain a passive understanding of the latter but fewer active speaking abilities. This was facilitated by the fact that despite the dislocation and high mortality rate of the deportation, his mother's parents had managed to stay together with the family and lived with them.

The existence of discernible linguistic and cultural differences between sub-communities of Central Asian Koreans is testament to their enfoldment within Soviet logics of commonality and separation for much of the twentieth century. This retains a key bearing on recent Goryeo saram lives, particularly their inter-ethnic and international encounters in contemporary 'post-socialist ${ }^{\text {' }}$ northeast Asia. My aim in this chapter is to argue that contact between Russian- and Chinesespeaking Koreans in Yanbian, a Korean autonomous prefecture in northeast China (Map 18.1), as well as the experiences of both in South Korea, serve as revealing lenses through which to examine questions over 'Koreanness' 5 in the Sino-Korean borderlands today. Based on fieldwork in Hunchun, ${ }^{6}$ a town in eastern Yanbian on the North Korean and Russian borders, I explore how Avram and many other Goryeo saram have seen their sphere of inter-ethnic and international experience expand dramatically in recent decades far beyond the steppes, deserts, cotton fields and

\footnotetext{
${ }^{4}$ My use of 'post-socialism' here follows Andrew Kipnis (2008, iv) application of the term to China and Chris Hann's $(2002,7)$ use of it in the Eurasian context. Both scholars highlight the importance of continuities between socialism and what comes afterwards, whilst also gesturing at the new mobilities and institutional configurations which the term implies.

${ }^{5}$ Whilst useful for my purposes here, this shorthand term lacks direct Korean/Russian/Chinese translations per se.

${ }^{6}$ Having a population today of around 200,000 people (roughly 50/50 Han Chinese and Joseonjok), Hunchun has long been a key borderland node of multinational and multiethnic encounter.
} 
melon-rich valleys where they were born. Greater personal mobility and information flows across the post-socialist era's porous state and communicative borders have not only brought collisions between the situational and negotiated 'way of being' Korean which emerged in the Soviet context, but has also had much the same effect among another group of partially 'cut off' Koreans, the Joseonjok. Encounters in present-day Hunchun invite a comparison of their case and that of the Goryeo saram, supplemented by examination of pertinent historical and social scientific literature, much of it by Goryeo saram and Joseonjok scholars themselves. Studying the two side-by-side reveals numerous striking parallels between the flexible modes of being 'Korean' which emerged in two large multiethnic socialist state contexts during the twentieth century, shown in the experiences of both groups in South Korea towards the end of the essay.

Diverse 'outside Korean' experiences in the Republic of Korea (ROK, South Korea) have received some journalistic and scholarly attention, considered in terms of 'diasporas' or 'transnational' groups (Park and Mun 2016). But encounters between Koreans from the formerUSSR and China have received more limited scrutiny. ${ }^{7}$ Hyun-Gwi Park's work $(2017,2018)$ in Russia's Primorskii krai (here also 'Primorye') is an insightful exception, but manifestations of Koreanness occurring in or beyond China remain understudied. Following a tradition laid down by Goryeo saram scholars themselves, my contribution to this area of study will in places trace a biographical trajectory, employing the views and life story of Avram, a pastor, translator, erstwhile scrap metal trader, farmer, and factory manager, as well as those of some other Yanbian-based Goryeo saram as vehicles for thematic movement. To begin, I provide a selective portrait of Hunchun which, in addition to serving as an account of the ethnographic field site under consideration, immediately raises a number of the thematic strands around contemporary 'ways of being' Korean in this borderland space.

Figure 18.1 Quad-lingual, quad-script sign on Hunchun China Mobile outlet

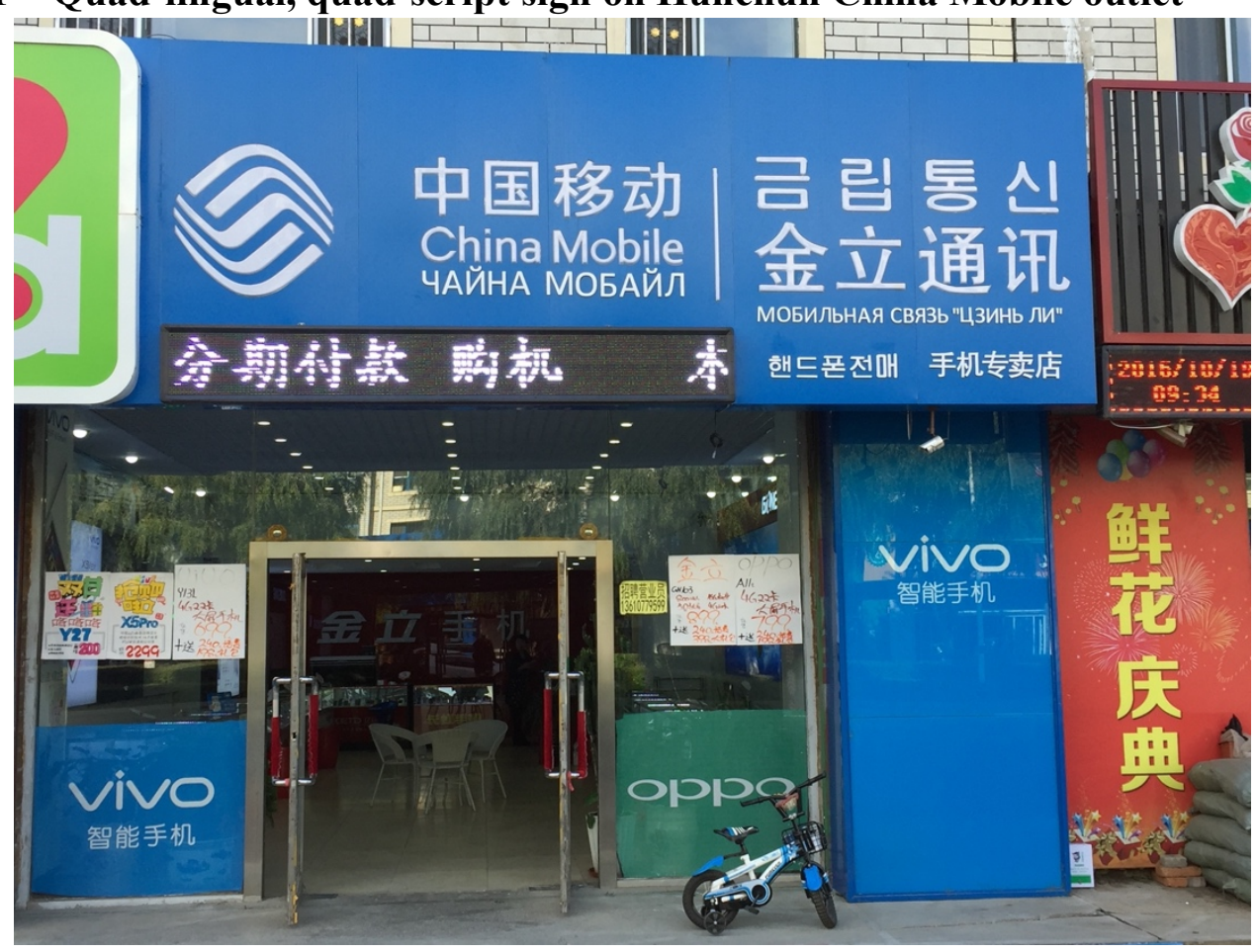

Photo: Ed Pulford

\footnotetext{
${ }^{7}$ This is a South Korean term: jaeoe dongpo (재외 동포).
} 


\section{Shifting Referents}

Hunchun's very urban fabric is clad in evidence of the ever-shifting mobilizations and reconfigurations of linguistic, ethnic and national identification - particularly Koreanness - in which local people are engaged. This is especially evident in the patchwork of cyphers which populate the town's trilingual Chinese/Korean/Russian signage, which occasionally also includes English (Figure 18.1). Depending on the intended audience and purpose, various genres of Koreanrelated representation include (see Figure 18.2, follow clockwise from top left): cues for a solely Chinese-speaking clientele seeking Korean fashion; blurring between North and South Korean symbols in shops promoting their 'international' wares (the more international the better, regardless of geopolitical dissonance); shifts from 'South Korean' to generic 'Korean' labels when signs are translated Chinese-Russian; subtly exclusive Korean-only signals to local Joseonjok that an establishment is run by members of their own group; and Russian-only hints at Korean quality and clinical expertise.

\section{Figure 18.2}



Clockwise from top left: 'Myeongdong' clothes shop - sign in Chinese only; Convenience store with flags of North and South Korea (plus China) to advertise (mostly South) Korean goods; Zhongyi 'South Korea City' trade centre - Chinese and Korean signage identifies with South Korea whilst Russian has simply 'Korean'; Saebyŏl / Xinmingxing Karaoke - Korean-only sign under roller shutter identifies the shop as Joseonjokowned; 'Yunhe Oral' dentist - Russian sign in top right reads 'Korean Dentistry by Victor Pak' Photos: Ed Pulford 
In broad terms, this selection of snapshots reveals multiple concurrent visions of Koreanness being selectively invoked in Hunchun, variously linked to a generic identity (as with Russian-language 'koreiskii' labels above), to the Korean ethnic group within China (as at the Joseonjok karaoke parlour) or to one or more states (as with the flags and use of Chinese/Korean Hanguo/Hanguk). This situation provides a visual China-based counterpart to the flexible ways in which formerSoviet Goryeo saram in Hunchun narrate and perform their own shifting Koreanness.

\section{The Sons}

The Son family were sought out in their hometown of Ussuriisk by a Hunchun-based Chinese agent who was looking for someone who knew how to make authentic versions of the Russian honey cake medovik. Wildly popular in borderland China where, by some curious process of semantic refraction, it is known as 'tiramisu' (tilamisu) with which it has little in common), the cake is among the products manufactured at Mr. Son's aunt's large bakery in Ussuriisk. Since Mr. Son and his wife, both in their late-20s, worked at the bakery, they made a good fit, and agreed to relocate with their three children. They now make the cakes in a second-floor room overlooking one of Hunchun's main roads, whilst downstairs a Han Chinese employee of the original agent sells their output on the Chinese social media app WeChat, dispatching several kinds of frozen medovik/tilamisu to all corners of northeast China.

Over dinner at the Sons' apartment one day, I ask them about their decision to move to Hunchun and whether it had had anything to do with Yanbian being a Korean area. 'No that didn't matter to us at all', says Mr. Son. 'It's only a few hours' drive away and we wanted a change, so that's why we came. It was as simple as that. Of course, the decision was made easier by the fact that Russia and China are officially friendly countries - it would have been different if we were thinking about moving to some other place'.

That the relationship between China and Russia here predominated over any Korean-oriented concerns was indicative of the Sons' pragmatic understanding that what mattered in Hunchun was their legal 'Russian' status. Yet identificatory ties to their country of citizenship go beyond the inevitable strictures of bureaucracy: all the ingredients needed to make their exceedingly Russian cakes, from flour to vinegar and bicarbonate of soda, are brought from over the border, whilst their shopfront offers a telling vision of the essentialized fairy-tale Russianness they are involved in marketing (Figure 18.3).

Yet as we continue eating and begin discussing Russia itself, the pendulum of the Sons' narrative swings decisively away from identifying too closely with the ethnic Russians who make up the majority population of Ussuriisk, and most of Hunchun's Russophone residents.

'I can't stand Russians', says Mrs. Son, using the term russkie which implies 'ethnic Russians' rather than rossiiskie ('citizens of Russia'). 'They're all zlye ("mean")', she continues, 'like if an old man falls over in the street in Ussuriisk, no one bothers to help him up. They have no concept of family or community values, and all anyone cares about back home is what you're wearing and how much your car costs'.

Were Koreans in Russia any better? I asked.

'Yes, I think we're generally kinder, happier people, and we have that in common with local people here in Hunchun. Although of course lots of us Goryeo saram have sadly been influenced by the Russians'. 
Figure 18.3 Russian cake shop

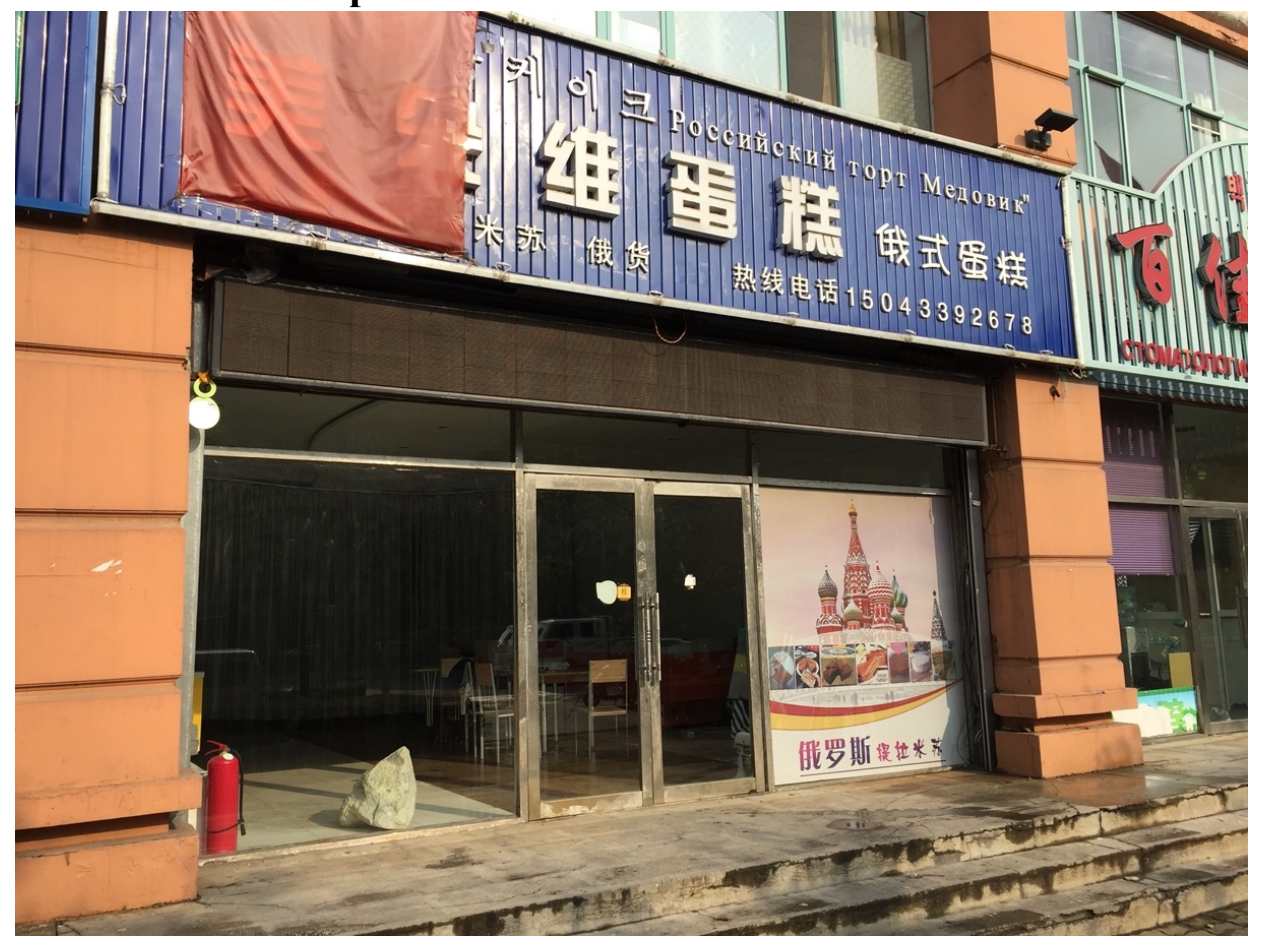

Russian cake shop run by Goryeo saram family in Hunchun soon after opening; note quintessentially 'Russian' window image of St. Basil's Cathedral. Top right of the sign is the Russian medovik, bottom left (partly obscured) is the Chinese tilamisu and top left is the Korean Anglicism k'eik'ú ('cake')

Photo: Ed Pulford

The meal which Mrs. Son had laid out before us seemed to capture a more benign version of this influence: uniquely Korean-Russian puktiai soup, a largely spice-free stew of potatoes and meat, ${ }^{8}$ sat alongside bowls of rice, processed pale pink Russian doktorskaia sausage, and a salad made with cucumber, tomato, mayonnaise and dill. As if in sympathy with the culturally syncretic nature of this spread, we move on to discuss culinary matters and I ask whether Korean food here in Hunchun differs much from that made by Goryeo saram back in Russia.

'Yes certainly', says Mrs. Son. 'Mainly the two have become different because of the different ingredients and seasonings we use. We had to survive on what you could get in Russia or Central Asia, but the Koreans here have a much wider selection'.

Whole books have been written comparing the fate of Chinese Koreans to the sharp but robust taste of the Korean gochu pepper (Ryu 2000; see Figure 18.10 below), and adopting this culinary metaphor for how Koreanness has become differently 'seasoned' in Russia and China seemed tempting. But in any case, before my mind strays too far into this perhaps simplistic territory Mr. Son intervenes.

'She doesn't know what she's talking about', he says grinning, 'I'm much more of a real Korean than her because I was born in Ussuriisk and so were my parents. How would someone from Dushanbe [the capital of Tajikistan] know about what Koreans are like?'

Does he speak Korean then? I ask in response to this provocative assertion of Ussuriisk's status as a kind of Korean homeland.

\footnotetext{
${ }^{8}$ Kor. bukjai, somewhat resembling the fermented soybean paste soup doenjang-jjigae and known in ROK as bukjang: lit. 'North [Hamgyeong] soup'.
} 
'Well, no, not really', he responds. 'Our grandparents still spoke it around 70 per cent of the time, our parents spoke Russian 70 per cent of the time, we can understand a bit, and as for them', he gestured at the couple's nine-year-old son who was sprawled imperiously in the middle of the living room floor watching TV in only his underwear, 'well they won't know any'.

Yet, as the Sons go on to explain, they were at least married according to Korean rites which involved wearing white and having all ceremonial functions completed by midday, although many of their Korean friends were choosing to do things the Russian way these days. Their youngest son will also be receiving the full Korean treatment for his first birthday party in several weeks' time, they assure me, and it is thus evident that Koreanness remains something to be asserted in certain domains at least, however inevitably Russian many aspects of their lives are here and back home.

\section{Vova}

Equally emblematic of the distinctly Russian overlay to the Goryeo saram presence in Hunchun is Vova Kim's position as leader of the town's 'Russian Club' (Russkii klub), an organization dedicated mainly to assisting Russian visitors to Hunchun with consumer disputes arising from their shopping (mis)adventures. Uzbekistan-born and 29 years old, Vova is a devout Putinist and a teetotal bodybuilder who cites various proofs of his status as a Russian 'patriot', including the fact that he only listens to Russian music and, he tells me more salaciously, sleeps exclusively with ethnically Russian women. In part because of such outlandish statements, he is known to other Russian-speaking Hunchun residents as a particularly kategoricheskii ('categorical') individual, but he disputes this reputation, vocally asserting that inter-ethnic differences mean little to him.

'The only boundaries that matter these days', he informs me one afternoon, 'are the limits of people's efficiency. Can you work efficiently or are you just lazy? - that's the key question of our time'. Seeing things this way, he says, allows him to look beyond racial or ethnic boundaries. As we pace Hunchun's streets checking up on various Chinese vendor contacts of his, he follows up with various statements about which groups of people in the world he considers to be the laziest, and I begin to wonder about the true border-dissolving extent of his views.

Indeed, many of my conversations with Vova suggest that he sees Koreans - broadly understood - as being a particularly efficient category of people.

'How is it that we are so able to adapt to different cultures?' he asks me rhetorically on another occasion. 'Let me tell you - it is because we have nunchi', he goes on, citing a difficult-to-translate Korean word implying, among other meanings in different contexts, situational awareness. 'It's sort of like Russian smekalka', he offers by way of explanation, using a term which has a more Russia-specific meaning closer to 'being able to extricate yourself from intractable snafus'.

'Koreans are successful everywhere - Russia, China, America - because we adapt. Like in Russia - we're all called Vladimir, Andrei, Aleksandr and we speak Russian even between ourselves. What other minority does that so readily? That's nunchi'. The difficult situation to which the Goryeo saram had to adapt was, of course, their tragedy-clouded deportation from the Russian Far East in 1937. But Vova's views about that are equally categorical: 'Stalin had to do it', he says. 'That was just the reality (real'nost') at the time, Koreans really were spying for the Japanese and after all, Koreans were only one of many different peoples who were deported'.

So, are Russian and Chinese Koreans more or less the same, I ask, each employing their nunchi to deal with distinct challenges in different national contexts? Vova qualifies his view slightly: 
'Well, it is certainly true that the Goryeo saram have lost something during their time among the Russians. Koreans here at least have their own prefecture, they are Koreans operating in their own locale (na svoem meste) which I suppose in some ways does make them more Korean than we are...'

Vova's allusions to varying ways of being Korean, and to the seemingly paradoxical state of affairs whereby the very act of abandoning certain Korean characteristics - names, language and so on - is considered an innately 'Korean' trait, provide insight into an attitude which was shared by most of my Goryeo saram and Joseonjok interlocutors. A consistent sense conveyed both explicitly and implicitly, peppered our interactions: Koreanness is a mutable thing to be identified with in a fragmentary and situational manner. More detailed discussion of this follows below, but first I return to the life of Avram to offer further evidence in this regard.

\section{Avram}

Avram's family background was a complex product of the organic cosmopolitanism which pervaded early-twentieth-century Primorye. His father was in fact not Korean at all but Chinese, yet having married Avram's Korean mother was swept up in the 1937 deportation which also carried a small proportion of local Chinese in its wake. Avram's inherited Chinese surname, he reports, had often raised questions about his identity among fellow-Koreans, and his confusing background had also purportedly made it impossible for him to enter the Communist Party of the Soviet Union (CPSU). Birth in Kazakhstan and an upbringing in Uzbekistan were followed by four and a half years of military service in Sakhalin and Kamchatka, and a working life as a builder and later manager of a brick factory in southern Kyrgyzstan. But in 1990 Avram, his fellow-Goryeo saram wife and their three children elected to move 'back' to the part of Russia from which his parents had been ejected. The decision to return to Primorye followed deadly rioting in the Kyrgyz town of Osh near where they lived, a flare-up of interethnic Uzbek/Kyrgyz tensions which were later seen by observers as one of a number of warning signs of the USSR's impending demise (Tishkov 1995). The relocation was thus intimately bound up with the fate of the Soviet polity whose vast geography and at-times-devastating policies had had a determinant effect on Avram's life and those of his immediate forebears. As Hyun-gwi Park (2013, 82-85) has pointed out, a modest and little-discussed return of Koreans from Central Asia to the Russian Far East had actually begun as early as the 1950s and 1960s, but Avram's move was part of a much larger-scale migration which followed late- and post-Soviet relaxations in mobility restrictions. Today, due in large part to this second wave of migration, an estimated 19,000 Goryeo saram live in Primorskii krai. ${ }^{9}$ The family settled in Partizansk (Map 18.1) in southeastern Primorye amidst a fin de siècle sense that everything was in flux.

"With all that sumatokha ("chaos") and the breakup of the Union, loads of different people were on the move', commented Avram. 'Koreans were returning to Primorye, South Korean Christian groups were coming into Russia and both Chinese and Korean Chinese were arriving from over the border to trade'.

This was the onset of a continuing period when myriad variant ways of being Korean have encountered one another. For a time Avram worked as a Korean-Russian translator for a group of South Korean Christians who were setting up operations in Partizansk, an experience which led

\footnotetext{
${ }^{9}$ Results of 2010 census list 18,824 Koreans, comprising around $1 \%$ of the local population. Source: http://www.gks.ru/free_doc/new_site/perepis2010/perepis_itogi1612.htm.
} 
him to a greater interest in spiritual matters. For a few months in 1993 he studied at a Moscow seminary funded by a Los Angeles-based Korean-American missionary group. Like many Primorye Koreans, Avram's ancestors had been converted to Russian Orthodoxy by late imperial missionaries, but a century later this new brand of Christianity served as a vehicle not for identification with any Russian state, but for a version of transnational Christian Koreanness which was or would have been novel to any recent Central Asian returnee. However, reflecting a common theme underlying the recent history of Goryeo saram encounters with matters South Korean, Avram's initial enthusiasm soon gave way to more equivocal views.

'At first these new beliefs seemed to provide all the answers. But I ultimately came to understand that the South Korean Christians are too serious a lot of the time', he reports. 'They're constantly stressing the question of belief, asking people if they believe or not and saying they'll go to hell if not. People should be more tolerant and flexible. And I'm tired of them quoting chapter and verse in isolation just to back up their points. You should take the religion as a whole to understand the message [...].' Avram then cited a Russian anekdot - a type of usually humorous long-form joke - to illustrate the dangers of not digesting scripture in toto:

'A thuggish-looking youth comes into a church, goes up to the priest, hits him in the face and then, laughing, says 'well father, isn't it written that if someone smites you on one cheek you should turn the other one?' But the priest, a former boxing champion, responds with a swift left hook which sends the youth reeling into a corner of the church. 'Yes, but it is also written that that which you give shall be returned unto you!' he says quietly. Witnessing the scuffle, some parishioners ask the deacon, 'what's going on there?' 'Ah they're just discussing the gospel', he responds to the terrified onlookers'.

It is easy to see how Avram's philosophical and relativistic approach to life's deeper questions, embedded in a distinctly Russian sense of humour, derives at least partly from the extraordinary shifts in circumstance which he has seen over the decades. Indeed, during the life of the Union Soviet citizens became intimately familiar with a repertoire of context-free quotations similar in form to Bible verses, namely the orphan 'dead quotes' from Lenin which decorated much of Soviet political doctrine (Yurchak 2017, 172-175). Avram's relativism emerges still more forcefully in his accounts of meetings with Joseonjok, which also began in the early 1990s, and took place in that most quintessential of post-Soviet spaces in the Russian Far East - the Chinese bazaar.

Unbeknownst to many Slavic inhabitants of the area, significant numbers of the 'Chinese' people who crossed the border to work on these markets in Primorye from the 1990s were Joseonjok (see Park 2013, 88). In Partizansk Avram had taken up his sixth profession, after solder, builder, factory manager, translator and priest, farming. Once these agricultural operations were established, his wife soon started selling some of their surplus produce at the 'Chinese' bazaar in nearby Ussuriisk (Map 18.1). Here in this small-scale private business setting, the first encounters occurred.

'Through my wife's work at the bazaar we got to know all kinds of Joseonjok', recalls Avram, 'they were wanting to sell lots of Chinese manufactured goods - slippers, machinery, electronics, everything. They also wanted buy things like timber and scrap metal'. As interactions increased, trust grew and by the mid-90s some of Avram's Joseonjok contacts had bought him a Japanesemade VW saloon car. In this vehicle he would drive the length and breadth of Primorye buying up scrap iron, cement and other detritus of the crumbling Soviet industrial base, and then arrange for it to be transported back to China where burgeoning post-reform industry was hungry for raw materials.

'I first came to Hunchun to visit my business contacts in 1994', Avram says, recalling a remarkably early first entry which was likely facilitated by inter-Korean connections: it was not 
until several years later in the late 1990s and early 2000s that Hunchun opened more fully to general Russian visitors. 'The place was nothing more than fanzy ${ }^{10}$ back then', he adds, 'but it was still nice here and I made a big mistake: my Chinese Korean friends offered to help me come and settle down here, but I refused. If I had done that then I could own half the town by now [...]'.

It was only after his wife's death that Avram reconsidered, eventually deciding to make the move to Hunchun in 2011. He arrived having years of experience on both sides of the border to draw upon when assessing differences and commonalities among Goryeo saram and Joseonjok: 'One key difference between Koreans here and us from Central Asia is language', he notes. 'Whilst most Goryeo saram of any age hardly speak a word of Korean, here you sometimes see the reverse, as many Yanbian Koreans of my age don't even speak Chinese if they come from small villages'. Parting ways with Mrs. Son, Avram also cited several Joseonjok traits which he considered more traditionally 'Korean' than general Goryeo saram mores, including respect for elders and less individualistic thinking. Yet it was evident that such comparisons were made not against some kind of monolithic yardstick of 'Korean' identity to which one could conform or not conform, but among distinct but equally flexible Koreannesses.

\section{Unstable Referents}

The Sons, Vova, Avram and other Goryeo saram of my acquaintance all described an unstable field of referents for what constituted appropriate or desirable 'Koreanness' in present-day Hunchun. Some traits or practices, notably the Sons' reference to their choice of wedding ceremony, were deemed to be more or less strong indications of being 'Korean' in a certain way. Yet others which might on the surface seem just as important as markers of ethnic identification appeared in fact to have become wholly uncoupled from association with Koreanness. Echoing some of the implications present in Vova's assertion that relinquishing Korean language competency somehow represented an inherently Korean capacity for adaptation, Avram made it clear that he too saw language ability as relatively unimportant, and certainly insufficient to make Joseonjok more 'Korean' in any particular way.

Even the old Koreans here who hardly speak any Chinese have still picked up Chinese ways', he said. 'You can see it in their traditions like burial for example - nowadays pretty much all Yanbian Koreans cremate their dead because they have to. But when I was back in Russia a few months ago, one of my Korean friends there was complaining that Russian Koreans are forgetting the old burial rites and saying how he'd buried his parents in the traditional way. Goryeo saram want to hold on to what they imagine are their traditions. But I told him, 'we have to look forward, not backwards'. This is one problem with Russian Koreans, they're all focused on the past $[\ldots]$.

Here then was an example of Avram rejecting efforts to identify more closely with 'traditional' Korean mores as incompatible with contemporary life. Adaptation was evidently important to him too.

Conversely, however, and adding another layer to the paradox, picking up the indisputably 'modern' habits of the world's most well-known Koreans - South Koreans - was hardly seen as

\footnotetext{
${ }^{10}$ A mostly pejorative term deriving from the Chinese fangzi (house) denoting in this case single-storey Chinese-style brick houses or rural dwellings.
} 
more validating in the eyes of Hunchun-based Goryeo saram. Viva, despite being widely considered by mutual friends of ours to be among the most wheeler-dealer-esque of Hunchun's Russian-speakers, railed against what he saw as the excessive ROK-derived materialism of modern-day Joseonjok.

'The South Koreans have done a good job', he said. 'But because of them the Koreans here are obsessed with money. Although', he reflected further, 'that might also have a lot to do with the Chinese as well'.

Avram too attributed a 'modern' tendency to conduct business in an aggressively capitalistic way among local Joseonjok to South Korean influence. Indeed, many of his past business dealings with Joseonjok partners had been plans to buy up hundreds of thousands of dollars-worth of Russian timber or import a new breed of pig from South Korea to Yanbian and Primorye. These quixotic schemes had come to naught, and this had left him with an impression that the influence of South Korean business in general was a pernicious one. But association of Joseonjok or Goryeo saram habits with explicitly labelled state entities such as South Korea was still no guarantee of attaining a version of Koreanness which could be unequivocally distinguished from generic 'modern' capitalist behaviour or indeed other national affiliations, such as the possible Chinese influence mentioned by Vova.

Taken together therefore, these reflections among people of quite different ages, experiences and dispositions - from the thoughtful Mrs. Son to the categorical Vova and the relativistic Avram revealed an ever-shifting repertoire of reference points which echoed many of the variant genres of Koreanness represented on Hunchun's shopfronts. Yet our talks also exhibited another trait which leads beyond the somewhat unadventurous conclusion that Russian-speaking Koreans have a 'flexible' attitude towards identity. ${ }^{11}$ Meta-reflection on Koreanness was a remarkably common conversation topic throughout my time in Hunchun, and this offers a clue as to the origins of these selectively deployed ways of being Korean. Claims made by interlocutors regarding intra-Central Asian distinctions among Soviet Koreans, language shift and Russification, nunchi and the deportation all reflect an impetus among Hunchun's Goryeo saram themselves to account for the layered historical and sociological root causes of their own (non-)Koreanness. These trace lines of causality down two main trajectories, firstly competing state-derived influences - those of the USSR, Russia, China, the Koreas - and secondly variations in politico-economic conditions under socialism or the market era. Mirroring the two cognate meanings of the word 'state', these two strands are of course not easily separable, since for people who have moved vast distances, bygone socio-economic 'states' are also products of now-defunct political 'states'. To take Avram or Vova's judgements about noxious South Korean influence on Joseonjok materialism as an example, nostalgia for simpler, egalitarian socialist times (which Vova, incidentally, is too young to remember personally), is also nostalgia for a time when Goryeo saram were thoroughly encompassed within Soviet/Central Asian/Russian-speaking environments very different from their trans- or inter-national presents. ${ }^{12}$

I now move on to discuss these increasingly trans/internationalized lives of many Goryeo saram in historical context. The following analysis is based on the past sociological contexts which many Goryeo saram friends themselves considered important in explaining their position. Through drawing on these I then move on to suggest both why situational approaches to Korean identity are common amongst my interlocutors, why these mirror the similarly flexible Joseonjok attitudes

\footnotetext{
${ }^{11}$ Hyun-Gwi Park (Park 2013, 78) observes a similar tendency amongst Russian Far Eastern Koreans, focusing on the 'relational' approach they exhibit to ethnicity.

${ }^{12}$ On post-Soviet nostalgia see the work of Svetlana Boym (2002) and Alexei Yurchak (2006).
} 
evident in Hunchun and, relatedly, why Koreanness emerges so often as a subject of contention and discussion. Ultimately, mobility in the China-Russia-Korea borderlands and the proliferation of self-reflexive identity questions are both intimately bound up with Yanbian and northeast Asia's post-socialist and post-Soviet status.

\section{From Entangled to Parallel Fates}

From being essentially a single large cohort of people, Goryeo saram and Joseonjok embarked on separate but remarkably parallel paths in each of the non-Korean states where they ended up. With both today's Yanbian - then 'Kando' (Kor.) / 'Jiandao' (Ch.) - and southern Primorye being settled simultaneously by famine-struck refugees from neighbouring Hamgyeong province from the 1870s (Jin 1993; Ban 1996), the two were in many regards not meaningfully distinct in their early years outside the Korean Peninsula. It was often chance as much as anything which determined whether the trip across the River Tumen left one in Russian or Chinese territory. Furthermore, and despite delineation of a Sino-Russian boundary via the 1860 Treaty of Peking, and its reaffirmation under the 1886 Hunchun Protocol, borders remained permeable for many subsequent decades, and those in Russia and China maintained considerable contact among themselves, as well as with people back in Hamgyeong. Tellingly, in the Chinese sector of this contiguous territory, the latenineteenth-century Qing authorities termed these Koreans Manzhou zhi Gaoliren ('Manchurian Goryeo people'), using precisely the Chinese-character term '高丽人' since applied to Korean citizens of the Commonwealth of Independent States in the ROK (Li 2012: 98).

Koreans on both sides of the Sino-Russian border were active participants in Communist, or at least leftist, struggles waged in the Russian (sBabichev 1959) and subsequent Chinese Civil Wars (Lee 1983), and also in resisting the Japanese occupations of southern Primorye (1918-1922) and Manchuria (1931-1945). The latter campaigns were inseparably linked to Korean liberation struggles against Japanese colonization of the Korean peninsula itself (1905-1945), and 1920s-40s events in both northeast China and the Russian/Soviet Far East had a decisive bearing on the later establishment of a socialist state in North Korea (Park 2005). In many regards therefore, the early history of the groups which later became known as Goryeo saram and Joseonjok were not just similar, but entangled.

As new Russian and Chinese-dominated polities emerged around them out of these regional political cataclysms, there resulted not so much a radical divergence between Goryeo saram and Joseonjok lives as their embarkation down two remarkably parallel tracks in their respective empires-turned-socialist states. On the Russian side following the 1922 establishment of the USSR, some Koreans lobbied for their own autonomous republic in southern Primorye (Chang 2016, 44) where they comprised a majority population in many locales, particularly the Poset area adjacent to Hunchun. This bid for self-governance, coupled with more suspicion - justified in Vova's view regarding their possible allegiance to the 1932-established Japanese-backed Manchukuo state over the border, underlay their 1937 deportation. Conditions in transit, which occurred in livestock wagons, were extremely harsh, and thousands perished. Avram's parents recounted to him that deportees were supposed to be given ten Soviet roubles each for the trip and five for children but did not receive the money. As Jon Chang (2016, 5-6) argues, even if the Soviet authorities justified their actions on the questionable basis that Koreanness was incompatible with socialism, this merciless treatment of the Goryeo saram was not a Soviet innovation but drew on longstanding Tsarist-era fears of a 'yellow peril' in the Far East. Those who, like Avram's family, managed to 
survive were forced to make a new life in mostly inhospitable parts of Central Asia, opening up new land to collective agriculture and engaging in back-breaking work which emphatically disproved the claim that they were somehow ill-suited to life in a state where 'labour' was of totemic importance.

Back in East Asia, two decades of turmoil after 1945 saw states falling and being created in rapid succession: Japan was ejected from Manchuria and Korea in 1945, the Soviet-backed DPRK established in 1948, the PRC founded in 1949, and Yanbian created as an autonomous unit within China in 1952 (Tai 2004). By the 1950s therefore, and following decades of unsettled mobility and turmoil, both Goryeo saram and Joseonjok were living roughly where they would remain for the next several decades. Indeed, limited mobility for both groups was a hallmark of the ensuing high socialist period as material poverty and strict registration regimes governing population movements (in sensitive border areas and the Sino-Soviet frontier specifically) kept Soviet and PRC citizens similarly static. ${ }^{13}$

\section{Domestic Koreannesses}

These parallel regimes of immobility were coterminous with a broader impetus for classification and registration in both bureaucratically centralist socialist states. Most significantly where Koreanness is concerned, this tendency was reflected in cognate Soviet and PRC regimes of categorization which, drawing on early Stalinist notions around what constituted a 'nation', determined officially permissible manifestations of ethnic difference. ${ }^{14}$ As was the case for all ethnic groups (Rus. natsional'nosti, Ch. minzu) in both places, identification as 'Korean' came to be expressed through a canonical repertoire of 'national' songs, dances, foods and other traditions which largely evacuated ethnicity of any claim to meaningful autonomy. Whilst motivated in large part by realpolitik concerns over controlling diverse populations, the softening of ethnicity was considered from a theoretical point of view to be a key step on the way to the Marxian 'withering away' of such categories, a process which would be followed by a similar disappearance of class and other social distinctions, and eventually the state itself.

In both contemporary Russia and China, the formalist understandings of how ethnic difference is demarcated laid down during the classificatory heyday of high socialism persist to this day. Avram's above statement about the need for Goryeo saram to look to the future where funerary rites are concerned serves as one example of this, for the promotion of particular frames within which ethnicity could exist often meant that non-canonical ethnically-specific practices, including religious traditions, were dismissed as superstitious or even 'feudal' practices. To clarify, I do not wish to suggest here that Avram or anyone else is merely a brainwashed vassal of statist ideology, but traces of the accepted official genres of ethnic identification, promoted by Soviet ethnological and other academic work, are difficult to avoid today when Goryeo saram scholars discuss 'Koreanness'. At the Overseas Koreans Foundation's 'Global Korean Convention' held in Seoul in

\footnotetext{
${ }^{13}$ The area adjacent to Hunchun on both the Chinese and Soviet sides was subject to permit and registration regimes. Whilst PRC citizens had to carry a 'border pass' (bianjingzheng) to prove residency in Hunchun or the right to visit, those in neighbouring Primorye had the letters 'PZ' (pogranichnaia zona - 'border zone') stamped in their domestic passports.

${ }^{14}$ The existence of Soviet 'nations' was notionally predicated on common 'language, territory, economic life and psychological make-up manifested in a community of culture' (Stalin 1936,8). The system which put this into practice - through registration of ethnicity on all official documentation - was adopted in the USSR from the 1930s and borrowed largely intact by the PRC in the 1950s.
} 
2017, for example, a majority of papers by Goryeo saram scholars focused on subjects including theatre, music and other performance-oriented activities. ${ }^{15}$

Where PRC-based sources are concerned, a Chinese-language search of the country's primary database of academic papers, 'Chinese National Knowledge Infrastructure' (CNKI), reveals that most work on the Joseonjok continues to revolve around form- and performance-based themes such as dance (wudao), music (yinyue), customs (minsu) and costume (fushi). Joseonjok-focused writing from Hunchun and Yanbian also stresses almost identical subjects (Jin 1993; Yi 2012), all of which buttress observations made by numerous anthropologists working on present-day PRC minzu concerning how ethnic identification has been canonized in often-Disneyfied song and dance-based terms. ${ }^{16}$

In raising this point about both Goryeo saram and Joseonjok state contexts, there are several things that I am not suggesting. Firstly, I do not wish to imply that outward performative manifestations of ethnic belonging such as song or dance are not important components of identity. Secondly, it is of course not the case that PRC and Soviet categories of Koreanness were based on nothing or plucked out of thin air, for many sensitive scholars and indigenous experts worked tirelessly to observe, record and promote a rich array of actually-existing cultural in both countries' early days of ethnic classification (Fei 1981 on PRC; Slezkine 1994 on USSR). Thirdly, I am not suggesting that these official visions for ethnic identity reigned hegemonic to the exclusion of all other possible conceptions of Goryeo saram or Joseonjok identification within their respective countries. Indeed, for all minority citizens of these vast polities, negotiations of ethnic difference were always much more flexible and emergent processes than state actors would have preferred, and populations did not have their ideas wholly subjugated to these notions any more than they became unable to think outside other state-promoted political categories.

What is key here, however, is the way in which these rigidly delineated state-sponsored schemata cast ethnic identification as a useful category only in certain contexts, thereby encouraging Soviet and PRC minority populations to adopt situational and negotiated approaches to ethnicity or, to borrow a phrase from anthropologist Stevan Harrell (2001), different 'ways of being ethnic' in different settings. Like many symbolic regimes within powerful centralizing states, ordinary people's conceptions of their ethnic identity did not exclude state-fostered ideas entirely, for even orthodox and rather wooden frames for marking out identity did come to acquire real meaning in the everyday lives of citizens. But as much as they were funds of material for understanding one's own wider group belonging, official natsional'nost' / minzu categories were also sites of struggle in negotiations over the place of minorities within larger polities. Much existing scholarship attests to how Soviet and PRC minorities have re-appropriated, selectively mobilized, and judiciously leveraged official categories to their own ends, including, to name a few, various Soviet groups studied by Svetlana Lure (2011) and Caroline Humphrey (2004), work in southwest China by Louisa Schein (2000), Ralph Litzinger (2000) and Stevan Harrell (2001), and Bulag's (2010) powerful argument concerning 'collaborative nationalism' among China's Mongols. Much of this work carries a strong historical inflection, tracing shifts in ethnic categorization over time to suggest that even in the pre-socialist Russian or Chinese empires, minority groups mobilized externally-imposed categories to their own ends.

Most applicable to the parallel Goryeo saram and Joseonjok cases are accounts of minority practices under high socialism. As Bulag suggests for the Chinese case, practices of 'collaborative

\footnotetext{
${ }^{15}$ Global Korean Convention 27-29 June 2017, Lotte Hotel, Seoul, ROK.

${ }^{16}$ On Disneyfication of PRC minzu see Schein (2000) on the Miao, Litzinger (2000) on the Yao and Bulag (2010) on the Mongols.
} 
nationalism' emerged in socialist conditions as minorities staked claims to a role as loyal cocreators of the multi-ethnic Chinese state, a position advanced in the Mongol case by revolutionary leader Ulanhu, who, as former-vice-president, remains the most important minority representative ever to attain a position of power in the PRC. During the 1980s, Ulanhu 'def[ied] Chinese attempts to erase nationality identities during the Cultural Revolution... [and] launched a discourse that sought to win 'recognition' for the minorities' equal 'contribution' to building the new China', in part by sponsoring a 1984 'Law on National Regional Autonomy' which affirmed that all nationalities had contributed to the state's creation (Bulag 2010, 146-147). Korean groups in both Soviet and PRC contexts have made precisely cognate assertions of their importance as cocontributors to wider socialist state projects, with each self-describing in scholarship as among the most loyal leftists during Bolshevik (Pak 2013) and CCP (Li 1988) guerrilla struggles, ${ }^{17}$ as operators of the most productive collective farms in Central Asia (Khan 2011), most talented scholars and cultural figures (Ryu 2000), and as disproportionately successful in attaining positions of leadership (Khan 2011). In numerous quite separate studies, Goryeo saram and Joseonjok scholars have spoken of these Korean groups as 'model minorities' (Rus. obraztsovoe men'shenstvo, Ch. mofan shaoshu minzu) (Yu and Choi 2012, 14; Khan 2014, 346) in their respective states, with the achievement of this status attributed to the very flexible identification with ethnic categories highlighted in my conversations with Goryeo saram interlocutors; appearing throughout is evidence of the paradox highlighted by Vova, whereby those identified as 'Korean' appear to be most successful at adapting to non-Korean circumstances. Drawing on influential work by Brackette Williams (1989), Litzinger suggests that ethnicity becomes a particularly significant notion 'when politically dominant groups set the terms of belonging to the national centre while subordinate groups are left to vie among themselves as to how best to mark their contribution to the national order' (Litzinger 2000, 239): in just this way, Koreanness mattered most under high socialism when what was at stake was succeeding in non-Korean environments.

In the post-socialist era, increased mobility and marketization have offered myriad settings in which to leverage ethnic and national belonging in new ways. On the Chinese side, Joseonjok actors in Hunchun and Yanbian generally have leapt at the chance to participate in a vogue for minzu-based tourism, with precisely the same colourful song-and-dance-based version of Koreanness once promoted by a bureaucratic Chinese state now being marketed back at Han Chinese visitors to the area's 'ethnic villages' and museums. Similar cases in which socialistartefact identities have been re-purposed in the market era include Schein's (2000) compelling account of Miao women mobilizing their treatment as exotically-dressed tourist curiosities in order to assert their own autonomy and earn money, and, in the political realm, Ron Suny (1999) and others' observations regarding re-emergent identities during the post-Soviet breakup. For CIS and PRC Koreans, the ability to reappraise and reconfigure shifting 'ways of being' Korean - Russianspeaking, Central Asian, Chinese or others - has been most useful when grasping the opportunities post-socialism presents for straddling newly-open national boundaries between China, Russia, Central Asian states, and the Koreas.

\footnotetext{
${ }^{17}$ Yanbian's Yanbian Ribao newspaper began publishing in Korean in 1948, a decade before its Chinese counterpart and a year before the PRC was even established (Wu 1998). For more on the Sinification of this newspaper in the late 1950 s, as well as the relationship between Marxism and nationalities theory in the PRC, see Dong Jo Shin's chapter in this volume.
} 


\section{Post-Socialist Parallels}

Post-Soviet openings have brought Koreans to Hunchun, revealing differences between variant Goryeo saram and Joseonjok Koreannesses. Conversely, these same processes have, in a different geography, offered further evidence of the formal parallels between Russian- and Chinese-speaking Korean experiences. From the onset of the post-socialist era as Yanbian and Primorye opened up, South Korea emerged as a new 'frontier' for mobile Koreans (Park 2015, 134). ${ }^{18}$ Moscow and Beijing normalized relations with South Korea in 1990 and 1992, respectively. Yet as growing numbers of Joseonjok and Goryeo saram began to spend time in the ROK, both found themselves confronted by quite different, much fewer negotiable conceptions of Korean identity than those which had developed domestically in each case. On both sides, academic consensus holds that, after an early honeymoon period when interest in all things linked to the economically burgeoning ROK spiked, from work, trade, investment, educational and cultural opportunities, and latterly 'Korean wave' phenomena, Goryeo saram and Joseonjok have subsequently become disillusioned and reverted to accepting more readily their post-Soviet and Chinese/Yanbian contexts.

The Korea-focused organizations, cultural groups and social clubs which effloresced in Central Asia in the late 1980s were suggestive of the manner in which this dynamic began to play out among Goryeo saram. Bearing names such as 'return' (vozvrashenie), 'rebirth' (vozrozhdenie) and 'homeland' (rodina) (Kim and Khan 2014), these spoke of a sense of rediscovery around the 'return' of many Goryeo saram to Primorye, and their notional 'homecoming' to a South Korea which, despite being a place bearing little historical relation to Russian Korean ancestry, was now envisioned as a lost patria (Lankov 2009). Yet many who experienced the ROK directly, either through migration, visits, or contact with South Koreans back in Russia (as in Avram's case), struggled with a sense that they were always viewed as a 'foreigner' (oegugin) (Kim 2017), or at best a kind of 'poor relation'. For Joseonjok, whilst notions of 'return' have been less salient among people who have not been deported from their home abutting the Korean Peninsula, the levels of interest - and subsequent disillusionment - in South Korean contact have been comparable. Indeed, today's Hunchun provides plentiful indications that these currents of fascination and disappointment run simultaneously. Shops such as Myeongdong and South Korea City attest to the Korean wave's persistent presence, but many such establishments, like the town's coffee shops and bars, are in fact owned and run by Joseonjok who have returned from the ROK having decided not to remain there. Although many do stay for long periods, and hundreds of thousands of Joseonjok comprise the ROK's largest single group of foreign residents (Park 2017), the eventual choice to return is a common one. In many cases this is motivated by struggles with a sense of difference and, at times, deliberate exclusion from prevailing ways of being Korean in the notional 'homeland'. As Caren Freeman $(2004,95)$ observes, these have come especially to the fore amidst efforts by policy-makers in South Korea to attract Joseonjok women to the country, both as cheap labourers and as wives for rural men who might 'restore family life' in depopulated rural areas. Promotion of the marriage drive in particular has asserted that Joseonjok integration will be a 'culturally seamless process' among members of the 'same ethnic group'. Yet this 'myth of ethnic homogeneity' has revealed itself indeed to be a myth, and, Freeman notes, 'contrary to [...] expectations Joseonjok brides discover immediately on arrival in South Korea that they do not blend easily with the local population'. With the same dynamic applying to Goryeo saram, it is highly significant that the barrage of Othering rejection from ROK citizens and non-acceptance of

\footnotetext{
${ }^{18}$ The Russian east too was being seen in these 'new frontier' (Kim 1995) terms for the kind of mobile Joseonjok who bought Avram his car.
} 
either group as real 'Koreans' in fact reinforce exactly the kind of flexible approach to ethnonational belonging discussed throughout here: in the Joseonjok case, for example, many of the Freeman's interlocutors in her rich ethnography 'expressed ambivalence about belonging to any nation state' (Freeman 2004, 96; see also 2011).

Furthermore, post-socialist collisions between powerful South Korean ideas about a priori and non-negotiable 'Koreanness' ${ }^{19}$ and more flexible 'ways of being' Korean evident among Goryeo saram and Joseonjok have underlain not only difficult personal experiences, but also vigorous discussion among scholars and laypeople alike of the veracity of the oft-pronounced phrase "we are all Koreans'. This partly accounts for why the notion of variant forms of 'Koreanness' emerged as a salient emic concern for Hunchun-based Goryeo saram over dinner or conversations in Century Square. On the academic level, encounters between situational and more monolithic notions of Koreanness have led Russophone scholars to debate at a high theoretical pitch whether the Goryeo saram should be considered a coherent ethnic group at all, or perhaps a 'meta-national' (Khan 2014, 349), 'super-national' (Iugai 2003) or 'sub-national' (Kireev 2012) collectivity instead. A consistent theme running throughout much of this theorizing is the inseparable relationship between Goryeo saram identity and the multiethnic Soviet/Russian context in which it emerged, with particular attention devoted to the constant negotiations with non-Korean interests on both the state and the everyday levels which have long been part of Soviet Korean lives.

Elsewhere, similar debates have occurred around the extent of Joseonjok realizations of their own 'Chineseness'. China- and ROK-based scholars examining Joseonjok migration from a political science perspective (Yu and Choi 2012), studying Yanbian-produced fictional work (Zhang 2016), and adopting a psychological approach to examine the outlook of Joseonjok students at Chinese universities (Piao and Qin 2012) invariably root the emergence of situational Joseonjokness within a multi-ethnic PRC context. Noting that Chinese Koreans are 'Chinese people' in important ways, these scholars employ terminology which in fact mirrors the above-noted distinction between rossiiskii and russkii, with Joseonjok being described as Zhongguo ren'people of China' - or even a category of 'overseas Chinese' (huaqiao) in their ROK encounters, rather than anything linking them to the ethnic Han (Hanzu) majority. For researchers such as Yanbian-based sociologist Li Meihua whose politically inflected work transparently buttresses orthodox CCP-promoted notions of unity amongst all minzu, inescapable Joseonjok Chineseness is a convenient conceit: experience of South Korean life has, Li $(2012,97)$ states, not 'weakened the national identity of the Korean Chinese, but enhanced their national identity as Chinese citizens'.

Yet however declarative such statements, identity questions do, as discussed throughout here, remain more open for both groups than the CCP or long-defunct CPSU would prefer. Indeed, searches for definitions of Koreanness continues to exhibit striking parallels on both sides, a situation tellingly illustrated by the mirrored titles of books by Goryeo saram historian and philosopher Valerii Khan (2009) and Joseonjok culturologist Ryu Wonmu (2000). ${ }^{20}$ The refrain 'who are we?' echoes on.

\footnotetext{
${ }^{19}$ North Korea too has of course long promoted a discourse of Korean oneness and its own ideas concerning who does and who does not constitute a 'true' Korean; but for post-socialist Russian- and Chinese-speaking Koreans, these have receded in importance along with the country's increased isolation.

${ }^{20}$ Khan's volume was first published in Korean in Seoul in 1998; the cover here is from the later-released Russian version which was published in Bishkek in 2009.
} 
Figures 18.4 and 18.5 Russian- and (Joseonjok) Korean-language books entitled 'Who are we?' Note both covers' mobilisation of canonical symbols of reified 'culture', notably architecture and cuisine
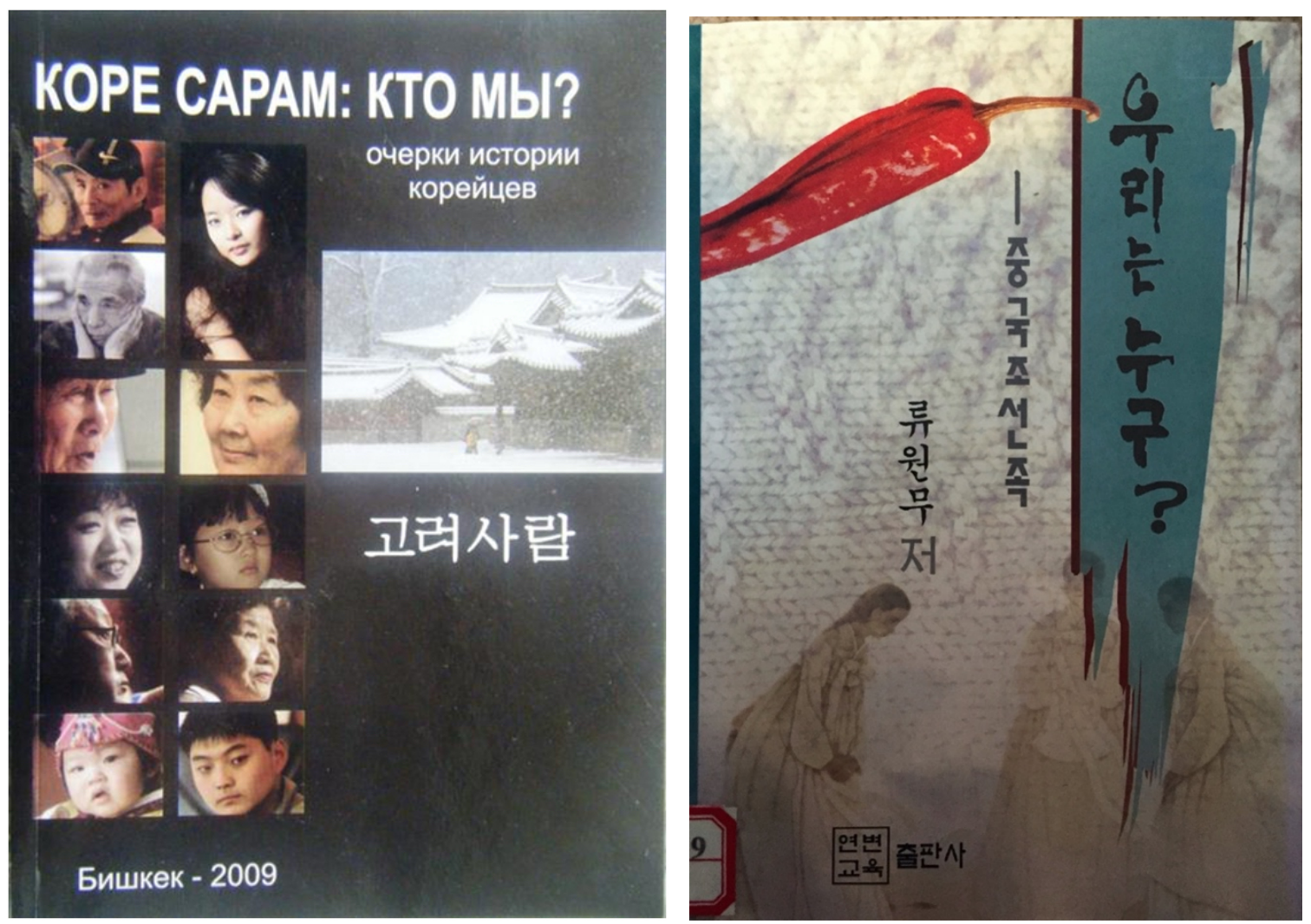

Photos: Ed Pulford

\section{Conclusion}

To Avram, Joseonjok appeared to have answered the 'who are we?' question successfully, to have 'come to terms' (smirilis) with life in their country of citizenship more fully than Goryeo saram. The long history of encounters with multiple Koreannesses which had led to him to this conclusion had also instilled in him a view of his own people as eternal malcontents, looking on as Joseonjok directed their energies towards improving their lot:

Yanbian Koreans understand that you need capital to move on in life these days, and so they work towards that', he said. 'But our lot are constantly looking backwards [nazad]. It's ridiculous [smeshno], Russian Koreans are always boasting that their family used to be rich, or that they had a grandfather who lived in South Korea and owned a yacht. I tell them, 'don't you even know that in those days there wasn't even a South Korea, and the whole place was a Japanese colony?' It shows that our Koreans don't know anything and are just living in the past.

Avram's cynicism about the gloomy fate of his own kind, reflections, incidentally, redolent of those one hears from many Russians, offered further eloquent testament to the distinct postsocialist circumstances in which Sino-Russian Korean encounters today occur. Today's Hunchun is indeed a place where capital is key, and as I have argued here, questions over identity and 
belonging are intimately intertwined with the new mobilities, money-making and -losing opportunities which have swirled around Primorye, Yanbian and the Korean peninsula over the past two and a half decades. In light of this, and the fact that each of the Goryeo saram and Joseonjok carry forward situational notions of ethnic belonging which emerged in classificationoriented socialist states during the twentieth century, the post-socialist condition of the area is key in the present-day. Also reflecting this is the fact that, as I have shown here, discussions over Koreanness take much more fragmented and demotic form than the semantic wrangling over Korean identity which, as Christian Park $(2017,3)$ notes drawing on John Borneman's work on Germanness in divided Berlin, lie at the heart of questions over national belonging in North and South Korea, and bear on methodological nationalism in ROK-based social science.

The importance of post-socialist circumstances here will likely not endure forever, as younger residents of the area, the children of today's adult Joseonjok and Goryeo saram returnees to the Russian Far East, will grow up with a more prosaic view of this confluence of Korean, Russian and Chinese spheres, and will be less preoccupied by questions of continuity and change than their forebears. But for now, a significant tool in perceiving where the limits of Koreanness lie, and 'decoding' the lives of many borderland-dwellers, will continue to be an understanding of this nexus of worlds as a distinctively post-socialist space.

\section{References}

Babichev, I. 1959. Uchastie Kitaiskikh I Koreiskikh Trudiashchikhsia v Grazhdanskoi Voine Na Dal'nem Vostoke [The Participation of Chinese and Korean Labourers in the Civil War in the Far East]. Tashkent: Gosudarstvennoe izdatel'stvo Uzbekskoi SSR.

Ban, Byung Yool. 1996. Korean Nationalist Activities in the Russian Far East and North Chientao, 1905-1921. PhD Disseration. University of Hawai'i at Manoa.

Boym, Svetlana. 2002. The Future of Nostalgia. New York, NY: Basic Books.

Bulag, Uradyn E. 2010. Collaborative Nationalism: The Politics of Friendship on China's Mongolian Frontier. Lanham, MD: Rowman \& Littlefield Publishers.

Chang, Jon K. 2016. Burnt by the Sun: The Koreans of the Russian Far East. Honolulu, HI: University of Hawai' $i$ Press.

Fei, Hsiao-tung. 1981. Towards a People's Anthropology. Beijing: New World Press.

Freeman, Caren. 2004. 'Marrying Up and Marrying Down: The Paradoxes of Marital Mobility for Chosonjok Brides in South Korea'. In Cross-Border Marriages: Gender and Mobility in Transnational Asia, ed. by Nicole Constable, 80-100. Philadelphia, PA: University of Pennsylvania Press.

Freeman, Caren. 2011. Making and Faking Kinship: Marriage and Labor Migration between China and South Korea. Ithaca, NY: Cornell University Press.

Hann, Chris (ed.). 2002. Postsocialism: Ideals, Ideologies, and Practices in Eurasia. Hove, UK: Psychology Press.

Harrell, Stevan. 2001. Ways of Being Ethnic in Southwest China. Seattle, WA: University of Washington Press.

Humphrey, Caroline. 2004. 'Cosmopolitanism and Kosmopolitizm in the Political Life of Soviet Citizens'. Focaal - European Journal of Anthropology 44: 138-152.

Iugai, Gerasim A. 2003. Obshchnost' narodov evrazii - ar'ev i superetnosov - kak natsional'naia ideia. rossiia $i$ koreia [The commonality of the peoples of eurasia - the aryans and super- 
ethnoses - as a national idea. russia and korea]. Moscow: Belovod'e.

Jin, Ze (ed.). 1993. Jilin Chaoxianzu [Jilin's Joseonjok]. Changchun: Jilin renmin chubanshe.

Khan, Valeriy Sergeevich. 2009. Kore Saram: Kto My? [Goryeo Saram: Who Are We?]. Bishkek: Izdatel'skii Tsentr 'Arkhi'.

Khan, Valeriy Sergeevich. 2011. 'Identity, Achievements and Social Status of the Koreans in Central Asia: Past and Present', talk given at Kyungpook University 14 October 2011. Seoul.

Khan, Valeriy Sergeevich. 2014. Koreitsy SNG I Koreia [Koreans of the CIS and Korea]. In Kore Saram: K 150-Letiiu Pereseleniia Koreitsev v Rossiiu, ed. by Viacheslav Kim, 346-352. Moscow: AivanLain.

Kim, German, and Valeriy Sergeevich Khan. 2014. Koreiskoe Dvizhenie v 1990-Kh Godakh [The Korean movement of the 1990s]. In Kore Saram: K 150-Letiiu Pereseleniia Koreitsev v Rossiiu, 301-307. Moscow: AivanLain.

Kim, Hakjoon. 1995. 'The Emergence of Siberia and the Russian Far East as a "New Frontier" for Koreans'. In Rediscovering Russia in Asia: Siberia and the Russian Far East, ed. by Stephen Kotkin and David Wolff, 302-311. Armonk, NY: M.E. Sharpe.

Kim, Vladimir. 2017. 'Pereselenie Koreitsev Tsentral'noi Azii I Ikh Prozhivaniia v Koree' [The resettlement of Central Asian Koreans in Korea]. In Global Korean Convention 27-29 June 2017, Russia and CIS Session, 27-39. Seoul: Global Korean Convention 2017.

Kipnis, Andrew B. 2008. China and Postsocialist Anthropology: Theorising Power and Society after Communism. Norwalk, CT: EastBridge.

Kireev, Anton Aleksandrovich. 2012. 'Koreitsy Na Rossiiskom Dal'nem Vostoke: Diaspora Ili Subnatsional'naia Obshchnost'? [Koreans in the Russian Far East: diaspora or sub-national collectivity?]. Izvestiia Vostochnogo Instituta 19 (1): 56-71.

Lankov, Andrei. 2009. 'Koreitsy SNG: Stranitsy Istorii' [Koreans of the CIS: Pages of History]. Koryosaram.ru. 7 June.

Lee, Chong-Sik. 1983. Revolutionary Struggle in Manchuria: Chinese Communism and Soviet Interest, 1922-1945. Berkeley, CA: University of California Press.

Li, Meihua. 2012. 'Zhongguo Chaoxianzu guojia rentong yanjiu zongshu' [Research review of the Korean Chinese national identity]. Journal of Dalian Nationalities University 14 (2): 97-102.

Li, Nenggao (ed.). 1988. Hunchunshi Minzu Zhi (1860-1987) [Gazetteer of Hunchun Minzu (18601987)]. Hunchun: Hunchunshi minzu zhi bianxiezu.

Litzinger, Ralph. 2000. Other Chinas: The Yao and the Politics of National Belonging. Durham, NC: Duke University Press.

Lure, Svetlana Vladimirovna. 2011. 'Druzhba Narodov' v SSSR: Natsional'nyi Proekt Ili Primer Spontannoi Mezhetnicheskoi Samoorganizatsii? ['Friendship of peoples' in the USSR: National project or example of spontaneous inter-ethnic self-organization?]. Obshchestvennye Nauki I Sovremennost' 4: 145-156.

Martin, Terry Dean. 2001. The Affirmative Action Empire: Nations and Nationalism in the Soviet Union, 1923-1939. Ithaca, NY: Cornell University Press.

Pak, Valentin P. 2013. Zemlia Vol'noi Nadezhdy: Trevozhnye Gody Primor'ia (1917-1922 Gg.): Svidetel'stva Epokhi [Land of free hope: Primore's years of disturbance (1917-1922): Evidence from the time]. Vladivostok: Valentin.

Park, Christian Joon. 2017. Narrating Transnational Koreans beyond Korean Diaspora. In Association of Asian Studies 'AAS in Asia' Conference. 24-27 June.

Park, Christian Joon, and Mun Hyona. 2016. 'Sahallin diaseupora haninui chogukjeok gyeongheomgwa uimi bunseok' [Analysis of the transnational experience of the Sakhalin 
Korean diaspora]. Yeongunonmun 2016 gusulsayeongu 7 (1): 137-186.

Park, Hyun-gwi. 2013. 'The Migration Regime among Koreans in the Russian Far East'. Inner Asia 15 (2013): 77-99.

Park, Hyun-gwi. 2017. The Displacement of Borders among Russian Koreans in Northeast Asia. Amsterdam: Amsterdam University Press.

Park, Hyun-Gwi. 2018. 'Betrayed by Trust: Kinship and Inter-Korean Relations across SinoRussian Border'. In Trust, Mistrust and “Calculation”: Sino-Russian Border Economies, ed. by Caroline Humphrey and Natalia Ryzhova, 101-120. Amsterdam: Amsterdam University Press.

Park, Hyun Ok. 2005. Two Dreams in One Bed: Empire, Social Life, and the Origins of the North Korean Revolution in Manchuria. Durham, NC: Duke University Press.

Park, Hyun-ok. 2015. The Capitalist Unconscious: From Korean Unification to Transnational Korea. New York, NY: Columbia University Press.

Piao, Tingji, and Qin Hongfan. 2012. 'Minzu gaoxiao daxuesheng minzu rentong, leguan he beiguan qinxiang yu qingxu leixing de guanxi' [Relationship among university students' ethnic identity, dispositional optimism and affects in nationalities university]. Journal of Dalian Nationalities University 14 (4): 289-303.

Ryu, Wonmu. 2000. Urineun Nugu? [Who are we?]. Tumen: Yanbian jiaoyu chubanshe.

Schein, Louisa. 2000. Minority Rules: The Miao and the Feminine in China's Cultural Politics. Durham, NC: Duke University Press.

Slezkine, Yuri. 1994. Arctic Mirrors: Russia and the Small Peoples of the North. Ithaca, NY: Cornell University Press.

Stalin, Joseph. 1936. Marxism and the National and Colonial Question. London: Lawrence \& Wishart.

Suny, Ronald Grigor. 1999. 'Provisional Stabilities: The Politics of Identities in Post-Soviet Eurasia.' International Security 24: 139-178.

Tai, Pingwu. 2004. 'Language Policy and Standardization of Korean in China'. In Language Policy in the People's Republic of China: Theory and Practice since 1949, ed. by Minglang Zhou and Hongkai Sun, 303-315. Boston, MA: Kluwer Academic Publishers.

Tishkov, Valery. 1995. "'Don’t Kill Me, I'm a Kyrgyz!": An Anthropological Analysis of Violence in the Osh Ethnic Conflict'. Journal of Peace Research 32 (2): 133-149.

Williams, Brackette F. 1989. 'A Class Act: Anthropology and the Race to Nation Across Ethnic Terrain'. Annual Review of Anthropology 18: 401-444.

Wu, Taigao (ed.). 1998. Yanbian Ribao 50 Nian Shi [The 50-Year History of Yanbian Daily]. Yanji: Yanbian renmin chubanshe.

Yi, Xiqing (ed.). 2012. Hunchun Chaoxianzu [Hunchun's Joseonjok]. Yanji: Yanbian jiaoyu chubanshe.

Yu, Shaobin, and Choi Heungsuk. 2012. 'Shenfen Rentong Zhuanbian de Yingxiang Yin Su Tanxi - Jiyu 16 Wei Zai Han Chaoxianzu Yimin de Jiegoushi Fangtan' [Change of the Sense of Identity among Korean Chinese Immigrants]. Overseas Chinese History Studies 4: 11-18.

Yurchak, Alexei. 2006. Everything Was Forever, Until It Was No More: The Last Soviet Generation. Princeton, NJ: Princeton University Press.

Yurchak, Alexei. 2017. 'The Canon and the Mushroom: Lenin, Sacredness, and Soviet Collapse'. HAU: Journal of Ethnographic Theory 7 (2): 165-198.

Zhang, Chunzhi. 2016. 'Chaoxianzu Minzu Shenfen Rentong de Wenxue Jiangou - Yi Shi Hua de 'Yanbian' He Jin Changyong de "Xi Ta" Wei Li' [Construction of Ethnic Identity in Joseonjok 
Literature: A Study Based on Shi Hua's 'Yanbian']. Journal of Yanbian University (Social Science) 49(3): 64-72.

\begin{abstract}
About the Author
ED PULFORD is a lecturer in Chinese Studies at the University of Manchester. He is the author of the book Mirrorlands, an anthro-historical account of life in the China-Russia borderlands, and his research focuses both on Chinese-Korean-Russian relations in northeast China, and northeast Asian indigenous groups. Work for this chapter was supported in part by a pre-doctoral fellowship at the Academy of Korean Studies (AKS) in Seongnam, South Korea May-August 2017.
\end{abstract}

